\title{
Treatment of motor and behavioural symptoms in three Lesch-Nyhan patients with intrathecal baclofen
}

\author{
Marco Pozzi ${ }^{1}$, Luigi Piccinini ${ }^{1}$, Maurizio Gallo ${ }^{2}$, Francesco Motta ${ }^{3}$, Sonia Radice ${ }^{4}$ and Emilio Clementi ${ }^{1,5^{*}}$
}

\begin{abstract}
Current therapies for the Lesch-Nyhan Syndrome (OMIM: 300322) are off-label and experimental, often leading to inconsistent outcomes. We here report the effects of an intrathecal baclofen therapy, carried out at the Scientific Institute Eugenio Medea (Lecco, Italy), on three patients who no longer received benefit from previous therapies. This treatment, as expected, ameliorated the motor symptoms and, unexpectedly, it also improved behavioural components. This result may involve a functional interaction between baclofen and dopamine, complemented by an anxiolytic effect. Our observations provide the rationale for the use of intrathecal baclofen administration in the therapy of the Lesch-Nyhan Syndrome.
\end{abstract}

Keywords: Lesch-Nyhan syndrome, Baclofen, Dystonia, Self-injurious behaviour

\section{Letter to the editor Introduction}

The Lesch-Nyhan Syndrome [1] (LN) (OMIM: 300322) involves dystonia, ballism, and self-injurious and aggressive behaviours. Although LN is severely disabling, no therapeutic standard can yet be indicated and treatment proceeds on the basis of isolated observations. Many therapies for LN, both pharmacological (antispastic drugs, antipsychotics, anti-parkinsonian drugs, dietary supplements) and cellular (enzyme replacement and stem cell therapies), are currently experimented, with inconsistent results [2]. We report on three patients with a genetic diagnosis of classical LN, who were referred to the Scientific Institute Eugenio Medea (Lecco, Italy) for rehabilitation. They were treated with intrathecal baclofen (ITB) and showed an improvement regarding both dystonia and pathological behaviours.

\section{Patients and methods}

Patient 1 was 19 years old at referral. During motor development, he never achieved head control, did not crawl or

\footnotetext{
*Correspondence: emilio.clementi@unimi.it

${ }^{1}$ Scientific Institute IRCCS Eugenio Medea, 23842 Bosisio Parini, Lecco, Italy ${ }^{5}$ Unit of Clinical Pharmacology, CNR Institute of Neuroscience, Department of Biomedical and Clinical Sciences L. Sacco, "Luigi Sacco" University Hospital, Università di Milano, Via GB Grassi 74, 20157 Milan, Italy

Full list of author information is available at the end of the article
}

walk; instead, he developed bilateral clubfoot and phasic extensor hypertonia of the upper limbs, with dystonia and ballism. His pathological behaviour involved very severe self-injury and involuntary aggression, by punching and biting. The patient constantly wore whole-body restraints in order to contain these exacerbations. Patient 2 was referred at 39 years of age. He never achieved head control, but crawled and walked until 9, when severe dystonia and ballism of the limbs began. He displayed severe finger biting and required permanent finger protection. Patient 3 was 20 years old at referral. He never achieved head control, crawled scantly and never walked. He developed strong retropulsive reactions, with dystonia involving neck and limbs, and ballism of the arms. By punching, he injured himself and attacked others. Patients were weaned off their previous therapies (Table 1) and subsequently implanted with the intrathecal drug delivery device Synchromed II - $20 \mathrm{ml}$ (Medtronic, Minneapolis, MN, USA). Individual ITB dosages were up titrated to achieve a satisfactory effect on dystonia.

\section{Results}

Dystonia was controlled with ITB dosages of 270 to $550 \mu \mathrm{g}$ per day. ITB improved the quality of sleep for all patients, as expected. This happened in the absence of serious adverse reactions; patient 3 only experienced 
Table 1 Patients' previous pharmacological therapies

\begin{tabular}{|c|c|c|c|c|c|c|}
\hline \multirow{4}{*}{$\begin{array}{l}\text { Patient } \\
1\end{array}$} & \multicolumn{3}{|c|}{ Remote therapeutic history } & \multicolumn{3}{|c|}{ Previous therapy before ITB placement } \\
\hline & \multirow{3}{*}{ Trihexyphenidyl } & \multirow{3}{*}{$4 \mathrm{mg} \times 3 /$ day } & \multirow{3}{*}{$\begin{array}{l}\text { Started in } 2006 \\
\text { Discontinued in } 2010\end{array}$} & \multirow{3}{*}{$\begin{array}{l}\text { S-adenosyl } \\
\text { methionine }\end{array}$} & \multirow[t]{3}{*}{400 mg x4/day } & Started in 2000 \\
\hline & & & & & & $\begin{array}{l}\text { Initial efficacy, } \\
\text { progressively lost }\end{array}$ \\
\hline & & & & & & Discontinued 24/04/2013 \\
\hline \multirow{12}{*}{2} & \multirow{12}{*}{ Risperidone } & \multirow{12}{*}{6 mg /day } & \multirow{12}{*}{$\begin{array}{l}\text { Started in } 1998 \\
\text { Discontinued in } 2011\end{array}$} & \multirow{3}{*}{ Levetiracetam } & \multirow[t]{3}{*}{250 mg x3/day } & Started in 2002 \\
\hline & & & & & & No efficacy \\
\hline & & & & & & $\begin{array}{l}\text { Weaned from 03/01/2014, } \\
\text { discontinued 20/02/2014 }\end{array}$ \\
\hline & & & & \multirow{4}{*}{ Clonazepam } & \multirow[t]{3}{*}{$1 \mathrm{mg} /$ day } & Started in 2002 \\
\hline & & & & & & $\begin{array}{l}\text { Partial efficacy on } \\
\text { spasticity }\end{array}$ \\
\hline & & & & & & $\begin{array}{l}\text { Weaned from 12/02/2014, } \\
\text { discontinued 21/02/2014 }\end{array}$ \\
\hline & & & & & \multirow[t]{3}{*}{$50 \mathrm{mg} /$ day } & Started in 2002 \\
\hline & & & & \multirow{2}{*}{ Sertraline } & & Scarce efficacy \\
\hline & & & & & & $\begin{array}{l}\text { Weaned from 08/02/2014, } \\
\text { discontinued 22/02/2014 }\end{array}$ \\
\hline & & & & \multirow{3}{*}{ Zopiclone } & \multirow[t]{3}{*}{$7.5 \mathrm{mg} /$ day } & Started in 2002 \\
\hline & & & & & & $\begin{array}{l}\text { Good efficacy on sleep } \\
\text { improvement }\end{array}$ \\
\hline & & & & & & $\begin{array}{l}\text { Weaned from 12/02/2014, } \\
\text { discontinued 21/02/2014 }\end{array}$ \\
\hline \multirow{4}{*}{3} & \multirow{4}{*}{$\begin{array}{l}\text { Enzyme replacement } \\
\text { therapy }\end{array}$} & \multirow{3}{*}{$\begin{array}{l}\text { Intrathecal } \\
\text { infusion of } \\
\text { leukocytes } \\
\text { (2/month) }\end{array}$} & & \multirow{4}{*}{ Gabapentin } & \multirow[t]{4}{*}{$400 \mathrm{mg} \times 4 /$ day } & Started in May, 2013 \\
\hline & & & $\begin{array}{l}\text { Started in } 1996 \\
\text { Discontinued in } 2010\end{array}$ & & & No efficacy \\
\hline & & & & & & \multirow{2}{*}{$\begin{array}{l}\text { Weaned from 23/01/2014 } \\
\text { discontinued 15/03/2014 }\end{array}$} \\
\hline & & $\begin{array}{l}\text { Intrathecal } \\
\text { infusion of } \\
\text { mesenchymal } \\
\text { stem cells }\end{array}$ & $\begin{array}{l}\text { Single administration in } \\
2012\end{array}$ & & & \\
\hline
\end{tabular}

mild drowsiness. In addition, within three days after reaching the stable ITB dosage, ballism was abolished and aggression and self-injurious behaviours ceased, thus allowing the removal of protective restraints (details in Tables 2 and 3). The beneficial effects of ITB therapy at unchanged dosages persisted throughout the follow up period (5 to 16 months).

\section{Discussion}

Currently, treatment approaches for LN are experimental, as therapeutic targets are not fully elucidated $[4,5]$. Dysregulation of dopaminergic pathways may be the cause of self-injurious behaviours in LN patients [6] and anatomical/physiological alterations were recently demonstrated in specific brain regions [7]. Impaired dopamine signalling during cerebral development could lead to the compensatory hypersensitivity of dopamine receptors, especially of the D1 subtype: this prevents the success of either dopaminergic drugs (which increase symptoms [8]) and antipsychotics (which do not target D1 receptors). The dopaminergic and GABAergic systems are connected at multiple levels and GABA has a prominent influence on dopamine release in the mesolimbic and nigrostriatal circuits [9]. Moreover, baclofen may serve as a functional antagonist of dopamine: $\mathrm{GABA}_{B}$ receptors are coupled to $\mathrm{G}$ proteins that inhibit adenylyl cyclase activity, while D1 dopamine receptors activate it. Baclofen may also have a direct anxiolytic effect [10] that could complement its activity on the dopaminergic balance and be useful for behavioural improvement. The use of baclofen and ITB for LN patients is not uncommon, a population study reported on ten users of oral baclofen and one of ITB, although it did not discuss therapeutic efficacy [2]. Good results of ITB therapy were also previously observed in two patients, although only little information was reported [11]. In order to compare available data, debate should be fostered between clinicians with different experiences on baclofen treatment in LN. Our cases further support the use of ITB in patients with LN within a multitargeted therapy that may ameliorate both motor and behavioural symptoms. ITB may represent a viable therapy for LN patients, especially in light of the severity of this 
Table 2 Patients' symptoms before and after treatment with intrathecal baclofen

\begin{tabular}{|c|c|c|c|c|}
\hline \multicolumn{2}{|l|}{$\begin{array}{l}\text { Patient } \\
\text { Pat }\end{array}$} & \multirow{2}{*}{$\begin{array}{l}1 \\
22\end{array}$} & \multirow{2}{*}{$\begin{array}{l}\mathbf{2} \\
23\end{array}$} & \multirow{2}{*}{$\begin{array}{l}\mathbf{3} \\
38\end{array}$} \\
\hline \multirow[t]{11}{*}{ Before ITB } & Dystonia: & & & \\
\hline & UDRS total ${ }^{a}$ & & & \\
\hline & Aggression & Yes & No & Yes \\
\hline & Self-injury ${ }^{b}$ : & & & \\
\hline & Mouth/lip biting & $2-3$ & 2 & $1-2$ \\
\hline & Finger biting & 10 & 20 & $3-4$ \\
\hline & Punching & 10 & 0 & $2-3$ \\
\hline & Restraint & Permanent whole body restraint & Permanent finger protection & None \\
\hline & Sleep ${ }^{c}:$ & & & \\
\hline & Awakenings & $7-8$ & $5-6$ & $5-6$ \\
\hline & Sleep hours & 2 & 4 & 4 \\
\hline \multicolumn{2}{|c|}{ Date of ITB implantation and age (years) } & $29 / 04 / 2013-19$ & $28 / 02 / 2014-39$ & $19 / 03 / 2014-20$ \\
\hline \multicolumn{2}{|c|}{ ITB dosage and follow-up duration (months) } & $380 \mu \mathrm{g} /$ day -16 & $270 \mu \mathrm{g} /$ day -6 & $550 \mu \mathrm{g} /$ day -5 \\
\hline \multirow[t]{12}{*}{ After ITB } & Dystonia: & 5 & 6.5 & 11 \\
\hline & UDRS total ${ }^{\mathrm{a}}$ & & & \\
\hline & Aggression & No & No & No \\
\hline & Self-injury ${ }^{b}$ : & & & \\
\hline & Mouth/lip biting & $0-1$ & 0 & 0 \\
\hline & Finger biting & 3 & 5 & 0 \\
\hline & Punching & 0 & 0 & 0 \\
\hline & Restraint & Occasional, right arm & None & None \\
\hline & Sleep ${ }^{c}:$ & & & \\
\hline & Awakenings & $1-2$ & 1 & 0 \\
\hline & Sleep hours & 5 & 6 & 5 \\
\hline & Notes & Improved verbal communication & - & $\begin{array}{l}\text { Persistent moderate nausea, } \\
\text { daytime drowsiness }\end{array}$ \\
\hline
\end{tabular}

Legend: a) Dystonia was scored using the UDRS scale [3]. Detailed scores are available in Table 3. b) Self-injury was scored by counting the daily episodes of different self-injurious behaviours, following interviews with caregivers. c) Quality of sleep was scored counting the number of awakenings per night and the average hours of uninterrupted sleep, following interviews with caregivers.

Table 3 Detailed scores from patients' UDRS scales

\begin{tabular}{|c|c|c|}
\hline Patient & Before ITB & After ITB \\
\hline \multirow{3}{*}{1} & Duration factor: 3 & Duration factor: 0 \\
\hline & $\begin{array}{l}\text { Motor severity factor: eyes and upper face: } 1 \text {, lower face: 3, jaw and } \\
\text { tongue: } 2 \text {, larynx: } 0 \text {, neck: } 2 \text {, shoulder and proximal arm. 2, distal arm } \\
\text { and hand (including elbow): } 3 \text {, pelvis and proximal leg: 3, distal leg and } \\
\text { foot (including knee): } 2 \text {, trunk: } 1 \text {. }\end{array}$ & $\begin{array}{l}\text { Motor severity factor: eyes and upper face: } 2 \text {, lower face: } 1 \text {, jaw and } \\
\text { tongue: } 1 \text {, larynx: } 0 \text {, neck: } 1 \text {, shoulder and proximal arm } 0 \text {, distal arm and } \\
\text { hand (including elbow): } 0 \text {, pelvis and proximal leg: } 0 \text {, distal leg and foot } \\
\text { (including knee): } 0 \text {, trunk: } 0 \text {. }\end{array}$ \\
\hline & Total $=22$ & Total $=5$ \\
\hline \multirow{3}{*}{2} & Duration factor: 4 & Duration factor: 0.5 \\
\hline & $\begin{array}{l}\text { Motor severity factor: eyes and upper face: } 1 \text {, lower face: } 4 \text {, jaw and } \\
\text { tongue: } 3 \text {, larynx: 0, neck: } 4 \text {, shoulder and proximal arm. 4, distal arm } \\
\text { and hand (including elbow): } 4 \text {, pelvis and proximal leg: } 4 \text {, distal leg and } \\
\text { foot (including knee): } 4 \text {, trunk: } 1 \text {. }\end{array}$ & $\begin{array}{l}\text { Motor severity factor: eyes and upper face: } 1 \text {, lower face: } 0 \text {, jaw and } \\
\text { tongue: } 1 \text {, larynx: } 1 \text {, neck: } 1 \text {, shoulder and proximal arm. } 0 \text {, distal arm } \\
\text { and hand (including elbow): } 0 \text {, pelvis and proximal leg: } 1 \text {, distal leg and } \\
\text { foot (including knee): } 0 \text {, trunk: } 0 \text {. }\end{array}$ \\
\hline & Total $=23$ & Total = 6.5 \\
\hline \multirow{3}{*}{3} & Duration factor: 4 & Duration factor: 1 \\
\hline & $\begin{array}{l}\text { Motor severity factor: eyes and upper face: } 1 \text {, lower face: } 4 \text {, jaw and } \\
\text { tongue: } 4 \text {, larynx: } 0 \text {, neck: } 3 \text {, shoulder and proximal arm. 3, distal arm } \\
\text { and hand (including elbow): } 2 \text {, pelvis and proximal leg: } 3 \text {, distal leg and } \\
\text { foot (including knee): } 4 \text {, trunk: } 0 \text {. }\end{array}$ & $\begin{array}{l}\text { Motor severity factor: eyes and upper face: 1, lower face: } 1 \text {, jaw and } \\
\text { tongue: } 2 \text {, larynx: } 0 \text {, neck: } 1 \text {, shoulder and proximal arm: } 1 \text {, distal arm } \\
\text { and hand (including elbow): } 1 \text {, pelvis and proximal leg: } 2 \text {, distal leg and } \\
\text { foot (including knee): } 1 \text {, trunk: } 0 \text {. }\end{array}$ \\
\hline & Total $=38$ & Total $=11$ \\
\hline
\end{tabular}


disease and of the lower comparative risk of severe side effects. Nevertheless, catheters for ITB administration may become infected, leading to removal in spite of partial ITB efficacy [12]. The risks of infection may be avoided by oral administration of baclofen, which is in general safe, apart from rare cases of hepatic toxicity [13]. We conclude that baclofen is potentially useful as a therapy for $\mathrm{LN}$, but that additional studies should be conducted, in order to properly assess its efficacy. Both intrathecal and oral administration routes should be investigated, with systematic measurements and long follow-up periods.

\section{Abbreviations}

LN: Lesch-Nyhan syndrome; ITB: Intrathecal baclofen.

\section{Competing interests}

The authors declare that they have no competing interests.

\section{Authors' contributions}

MP: research conception, manuscript preparation. LP: research conception, patient management, manuscript review. MG, FM: patient management, data collection, manuscript review. SR, EC: research conception, manuscript review. All authors read and approved the final version of the manuscript.

\section{Acknowledgements}

We are thankful to dr. Valeria Padovano for language revision.

\section{Funding sources}

This work was supported by Agenzia Italiana del Farmaco (AIFA) and by the Italian Ministry of Health (Ricerca Corrente 2014, to EC). The funding public institutions had no role in any part of the work.

\section{Author details}

${ }^{1}$ Scientific Institute IRCCS Eugenio Medea, 23842 Bosisio Parini, Lecco, Italy. ${ }^{2}$ Scuola di Specializzazione in Medicina Fisica e Riabilitativa, Università di Milano, 20122 Milan, Italy. ${ }^{3}$ Paediatric Orthopedics and Traumatology, Children's Hospital V. Buzzi, 20126 Milan, Italy. ${ }^{4}$ Unit of Clinical Pharmacology, Department of Biomedical and Clinical Sciences L. Sacco, "Luigi Sacco" University Hospital, Università di Milano, 20157 Milan, Italy. ${ }^{5}$ Unit of Clinical Pharmacology, CNR Institute of Neuroscience, Department of Biomedical and Clinical Sciences L. Sacco, "Luigi Sacco" University Hospital, Università di Milano, Via GB Grassi 74, 20157 Milan, Italy.

Received: 13 October 2014 Accepted: 3 December 2014

Published online: 12 December 2014

\section{References}

1. Lesch M, Nyhan WL: A familial disorder of uric acid metabolism and central nervous system function. Am J Med 1964, 36:561-570.

2. McCarthy GT, Green EM, Ogunbona O, Simmonds HA, Fairbanks L, Pountney T, Bryant E: A population study of Lesch-Nyhan disease in the UK. Dev Med Child Neurol 2011, 53(1):34-39.

3. Comella CL, Leurgans S, Wuu J, Stebbins GT, Chmura T, Dystonia Study Group: Rating scales for dystonia: a multicenter assessment. Mov Disord 2003, 18(3):303-312.

4. Jankovic J, Caskey TC, Stout JT, Butler IJ: Lesch-Nyhan syndrome: a study of motor behavior and cerebrospinal fluid neurotransmitters. Ann Neurol 1988, 23(5):466-469.

5. García MG, Puig JG, Torres RJ: Adenosine, dopamine and serotonin receptors imbalance in lymphocytes of Lesch-Nyhan patients. J Inherit Metab Dis 2012, 35(6):1129-1135.

6. Goldstein M: Dopaminergic mechanisms in self-inflicting biting behavior. Psychopharmacol Bull 1989, 25(3):349-352.

7. Schretlen DJ, Varvaris M, Ho TE, Vannorsdall TD, Gordon B, Harris JC, Jinnah HA: Regional brain volume abnormalities in Lesch-Nyhan disease and its variants: a cross-sectional study. Lancet Neurol 2013, 12(12):1151-1158.

8. Visser JE, Schretlen DJ, Bloem BR, Jinnah HA: Levodopa is not a useful treatment for Lesch-Nyhan disease. Mov Disord 2011, 26(4):746-749.
9. Barrot M, Sesack SR, Georges F, Pistis M, Hong S, Jhou TC: Braking dopamine systems: a new GABA master structure for mesolimbic and nigrostriatal functions. J Neurosci 2012, 32(41):14094-14101.

10. Margetis K, Papageorgiou G, Gatzonis S, Politis K, Siatouni A, Sakas D: Intrathecal baclofen improves psychiatric symptoms in spasticity patients. J Clin Psychopharmacol 2014, 34(3):374-379.

11. Jinnah HA, Visser JE, Harris JC, Verdu A, Larovere L, Ceballos-Picot I, Gonzalez-Alegre P, Neychev V, Torres RJ, Dulac O, Desguerre I, Schretlen DJ, Robey KL, Barabas G, Bloem BR, Nyhan W, De Kremer R, Eddey GE, Puig JG, Reich SG, Lesch-Nyhan Disease International Study Group: Delineation of the motor disorder of Lesch-Nyhan disease. Brain 2006, 129(Pt 5):1201-1217.

12. Deon LL, Kalichman MA, Booth CL, Slavin KV, Gaebler-Spira DJ: Pallidal deep-brain stimulation associated with complete remission of self-injurious behaviors in a patient with Lesch-Nyhan syndrome: a case report. J Child Neurol 2012, 27(1):117-120.

13. Kiel LB, Hoegberg LC, Jansen T, Petersen JA, Dalhoff KP: A nationwide register-based survey of baclofen toxicity. Basic Clin Pharmacol Toxicol 2014, doi:10.1111/bcpt.12344

doi:10.1186/s13023-014-0208-3

Cite this article as: Pozzi et al.: Treatment of motor and behavioural symptoms in three Lesch-Nyhan patients with intrathecal baclofen. Orphanet Journal of Rare Diseases 2014 9:208.

\section{Submit your next manuscript to BioMed Central and take full advantage of:}

- Convenient online submission

- Thorough peer review

- No space constraints or color figure charges

- Immediate publication on acceptance

- Inclusion in PubMed, CAS, Scopus and Google Scholar

- Research which is freely available for redistribution 